\title{
Stigmatisasi dan Perilaku Diskriminatif pada Perempuan Bertato
}

\author{
Fatmawati
}

\author{
Jamaluddin Arifin \\ Universitas Muhammadiyah Makassar \\ jamaluddinarifin@unismuh.ac.id
}

\author{
Suardi \\ Universitas Muhammadiyah Makassar \\ suardi@unismuh.ac.id
}

\begin{abstract}
ABSTRAK
Munculnya fenomena tato sebagai sebuah subkultur dalam masyarakat, khususnya di kalangan perempuan di Kota Makassar.Fenomena tersebut bertentangan dengan Agama dan kebudayaan bahkan dominan yang dimiliki oleh masyarakat Kota Makassar yaitu stigmatisasi diskriminasi terhadap para perempuan bertato tersebut. Penelitian ini digunakan untuk menjawab empat masalah pokok, yaitu bagaimana stigmatisasi, serta diskriminasi dalam masyarakat, bahkan dampak yang di timbulkan adanya stigmatisasi dan diskriminatif masyarakat terhadap perempuan bertato, dan solusi apa yang harus di lakukan dalam menyikapi masalah ini. Penelitian ini merupakan suatu penelitian etnografi yang bersifat deskriptif dengan menggunakan data kualitatif. Penggalian data dilakukan dengan cara observasi, wawancara dan beberapa data sekunder yang mendukung penelitian ini, seperti buku-buku, browsing internet, dan penelitian sebelumnya. Hasil penelitian menunjukkan bahwa faktor penyebab perempuan menggunakan tato di Kota Makassar khusus di Keluaran Karunrung beragam meliputi faktor intenal dan eksternal.
\end{abstract}

Kata Kunci : Stigmatisasi, Diskriminatif, Tato.

\section{PENDAHULUAN}

Pada hakekatnya, manusia merupakan makhluk ciptaan Tuhan yang terdiri dari tubuh dan jiwa sebagai satu kesatuan. Tubuh merupakan bagian dari materi jiwa yang dapat dipandang, diraba, bahkan disakiti. Tubuh adalah bagian yang paling tampak sehingga dijadikan simbol nyata bagi setiap jiwa dalam penyampaian pesan. Setiap manusia bisa mengontrol peranan mereka sendiri, khususnya dalam hal penanganan pada tubuh. Orang lain bebas menginterpretasikan makna tato yang terdapat pada tubuh pengguna tato.

Tato berasal dari kata "tatau" dalam bahasa Tahiti.Menurut Oxford Encyclopedic Dictionary - tatto v.t. Mark (skin) with permanent pattern or design by puncturing it and inserting pigment; make (design) thus- $n$. Tattoing (Tahitian tatau).Tato adalah menandai (pada kulit) menggunakan pola atau design secara permanen dengan membubuhkan dan memasukkan cairan berwarna yang diukir dengan menggunakan alat sejenis jarum. Untuk saat ini mendengar kata tato saja sudah terlintas di benak kita masing-masing, 
demikian juga image bahwa segala sesuatu yang berhubungan dengan tato, pasti berhubungan dengan tindak kriminal, citra buruk terhadap perempuan pengguna tato sudah melekat di masyarakat.

Stigmatisasi masyarakat bahwasanya setiap orang yang menggunakan tato jika seorang pria akan dianggap identik dengan pelaku kejahatan, kekerasan, perampokandan tindak kriminal lainnya, sedangkan untuk penggunaan tato pada perempuan diidentikkan dengan wanita nakal, pelacur dan mucikari. Stigmatisasi yang kearah negative seperti ini secara tidak langsung mendapat pengesahan di berbagai belahan kota di Indonesia, dan ketika seorang perempuan bertato berada pada suatu kelompok atau di tengah-tengah perempuan yang tidak menggunakan tato dia akan didiskriminatifi oleh kaum perempuan lain yang tidak menggunakan tato, karena perempuan ketika menggunakan tato sudah memiliki cap atau label tersendiri dimata perempuan atau masyarkat lainnya.

Makassar merupakan salah satu kota terbesar di wilayah Indonesia bagian timur. Dimana hal ini memungkinkan mudah mengakses informasi serta masyarakatnya akan mendapat pengaruh dari luar yang cukup besar. Hal inilah yang mendasari sehingga penulis melakukan penelitian untuk mendapatkan informasi tentang"Stigmatisasi dan Perilaku Diskriminatif pada Perempuan Bertato di Kota Makassar"

\section{LANDASAN TEORI}

Gilin dan Gilin (dalam Soekanto, 2012; 263) perubahan sosial adalah perubahan yang terjadi sebagai suatu variasi dari cara hidup yang telah diterima karena adanya perubahan kondisi geografi, kebudayaan material, komposisi penduduk ideologi maupun adanya difusi atau penemuan-penemuan baru dalam masyarakat. Solo Soemardjan (dalam Soekanto,2012; 263) perubahan sosial adalah perubahan-perubahan pada lembaga lembaga kemasyarakatan di dalam suatu masyarakat, yang mempengaruhi system sosialny, termasuk di dalamnya nilai-nilai, sikap, dan pola prilaku diantara kelompokkelompok dalam masyarakat. Tekanan pada definisi tersebut terletak pada lembagalembaga kemasyarakatan sebagai himpunan pokok manusia, yang kemudian memengaruhi segi-segi sturuktur masyarakat lainnya.Dalam penelitian yang berhubungan dengan stigma, maka peneliti akan menggunakan teori stigma yang dikemukakan oleh Erving Goffman. Stigma merupakan tanda-tanda yang dibuat pada tubuh seseorang untuk diperlihatkan dan menginformasikan kepada masyarakat bahwa orang-orang yang mempunyai tanda-tanda tersebut merupakan seorang buruh, criminal, atau seorang penghianat.Tanda-tanda tersebut merupakan suatu ungkapan atas ketidak wajaran dan 
keburukan status moral yang dimiliki oleh seseorang (Goffman, 1963:1).Goffman menyebutkan 3 tipe stigma yang diberikan terhadap seseorang, yaitu :

1) Stigma yang berhubungan dengan kecacatan pada tubuh seseorang (cacat fisik)

2) Stigma yang berhubungan dengan kerusakan-kerusakan karakter individu, missal homosexuality.

3) Stigma yang berhubungan dengan ras, bangsa dan agama.

Ada 2 tipe individu yang simpati dan memberikan dukungan kepada orang yang terstigm Tipe yang pertama yaitu orang yang mempunyai stigma yang sama. Orang-orang seperti ini dapat memberikan saran karena mereka pernah mengalami hal yg sama. (Goffman, 1963:19-20).Tipe yang kedua merupakan orang-orang yang karena situasi tertentu menjadi dekat dengan orang yang terstigma.Goffman memberi istilah "wise" bagi orang-orang yang termasuk pada tipe kedua.

1) Labeling

MenurutHoward S. Beckertindakan perilaku menyimpang sesungguhnya tidak ada.Setiap tindakan sebenarnya bersifat"netral" dan "relative".Artinya, makna tindakan itu relatif tergantung pada sudut pandang orang yang menilainya.Sebuah tindakan disebut perilaku menyimpang karena orang lain/masytarakat memaknai dan menamainya (labeling) sebagai perilaku menyimpang.Jika orang/ masyarakat tidak menyebut sebuah tindakan sebagai perilaku menyimpang, maka perilaku menyimpang itu tidak ada. Penyebutan sebuah tindakan parilaku menyimpang sangat bergantung pada proses deteksi, definisi, dan tanggapan seseorang terhadap sebuah tindakan.Teori Stigmatisasi merupakan tanda-tanda yang dibuat pada tubuh seseorang untuk diperlihatkan dan menginformasikan kepada masyarakat bahwa orang-orang yang mempunyai tanda-tanda tersebut merupakan seorang buruh, criminal, atau seorang penghianat. Teori labeling ini adalah pemberian cap atau label terhadap seseorang yang sudah dicap oleh masyarakat kepada orang yang diberikan label karena adanya tindakan perilaku menyimpang. Oleh sebab itu perempuan pengguna tato dicap sebagai perempuan melanggar norma-norma dan aturan yang berlaku.

2) Teori Diskriminatif

Diskrimintif adalah sikap yang merupakan usaha untuk membedakan secara sengaja terhadap golongan-golongan yang berkaitan dengan kepentingan tertentu ; dalam diskriminatif, golongan tertentu diperlakukan berbeda dengan golongan-golongan lain ; pembedaan itu dapat didasarkan pada suku bangsa, agama, mayoritas, atau bahkan minoritas dalam masyarakat. Jika mendengar kata diskriminatif pasti yang terbayang 
dalam ingatan adanya suatu perlakuan yang tidak adil dan perlakuan yang berbeda oleh sekelompok masyrakat.Hal ini sesuai dengan pengertian yang diutarakan oleh Fulthoni, et.al (2009:8), pada dasarnya diskriminatif adalah pembedaan perlakuan.Diskriminatif adalah perlakuan yang tidak adil dan tidak seimbang yang dilakukan untuk membedakan terhadap perorangan, atau kelompok berdasarkan sesuatu kategorikal atau atribut-atribut khas seperti berdasarkan ras, kesukubangsaan, agama, atau keanggotaan kelas-kelas sosial. Dalam rangka ini dapat juga kita kemukakan melalui definisi dari Doob dalam Liliweri (2005:218), lebih jauh mengakui bahwa diskriminatif adalah perilaku yang di tunjukkan untuk mencelah suatu kelompok, atau membatasi kelompok lain yang berusahan memiliki atau mendapatkan sumber daya. Salah satu bentuk diskriminatif terjadi pada perempuan bertato.

Tato adalah sesuatu yang berada dibelakang dengan makna sendiri sebagai bagian dari penanda ritual, atau bahkan pada suku dayak kenyah, ia sebagai penanda bagi suatu status sosial tertentu, tato bagi orang mentawai sebagai tanda dan alat komunikasi berupa Kartu Tanda Penduduk (KTP), seperti suku, negeri asal, dan malah identitas bahwa ia pernah membunuh orang dan tepatnya sebagai strata sosial yang bersangkutan (Haluan, 18 Juni 2003). Dalam Kamus Bahasa Inggris, istilah tato berasal dari kata tattoo yang artinya pencacahan atau pengerajahan. Sedangkan dalam Kamus Umum Bahasa Indonesia, tato atau rajah adalah lukisan atau gambar pada kulit tubuh dengan cara menusuki kulit dengan jarum halus kemudian memasukkan zat warna ke dalam luka-luka itu.

Tubuh bagi sebagian orang, menjadi media tepat untuk berekspresi dan eksperimen. Tak heran jika kemudian timbul aktivitas dekorasi seperti Tatto, eksploitasi ini untuk sebagian besar pelakunya ditujukan untuk gaya dan pernyataan pemberontakan. Jika awalnya orang melakukan eksploitasi tubuh untuk tujuan yang lebih khusus, misalkan untuk identitas pada suatu budaya tertentu, kini eksplotasi tubuh melalu tatto, berkembang karena mode dan gaya hidup.

\section{METODE PENELITIAN}

Jenis penelitian ini adalah kuantitatif deskriptif, yaitu jenis penelitian yang menjelaskan atau menggambarkan suatu fenomena, dalam hal ini stigmatisasi dan perilaku diskriminatif pada perempuan bertato (studi kasus di kota Makassar)..Sumber data terdiri dari data primer dan data sekunder.Instrumen penelitian adalah peneliti sendiri sebagai instrumen utama dan alat seperti kamera, alat perekam dan lembar 
observasi.Informan ditentukan secara purposive samplingyang berjumlah 8 orang.Teknik pengumpulan data yaitu observasi, wawancara dan dokumntasi, Analisa data yang digunakan pada penelitian ini memiliki beberapa tahapan seperti mengorganisasikan data, pengelompokan data, menguji asumsi data, mencari alternatif penjelasan bagi data dan akhirnya menuliskan hasil penelitian. Teknik keabsahan data triangulasi waktu, teknik dan sumber.

\section{PEMBAHASAN}

1) Stigmatisasi masyarakat pada perempuan bertato

Latar belakang perempuan menggunakan tato adalah dasar dari keinginan sendiri atau tuntutan gaya hidup di mana dewasa ini tato menjadi salah satu gaya hidup yang bukan hanya terjadi di daerah perkotaan bahkan sudah memasuki daerah pedesaan.Selama satu dekade terakhir tato menjadi semakin populer di kalangan masyarakat. Hal ini dapat dilihat dari semakin banyaknya orang-orang yang mentato tubuhnya. Perkembangan tato semakin terasa ketika rezim orde baru runtuh.Kebebasan dalam berekspresi dan menyatakan pendapat menjadi lebih longgar dan semakin wajar.Kebebasan tersebut tidak hanya dirasakan oleh pelaku politik saja, namun juga berdampak luas kepada masyarakat.Salah satunya para seniman dan kaum muda yang lebih kritis dan reaksioner terhadap lingkungan sekitarnya.Salah satu bentuk nyata dari kebebasan tersebut adalah perkembangan tato yang semakin pesat.Tato seolah-olah menjadi tren dan gaya hidup yang baru dari masyarakat modern saat ini. Tidak ada lagi kekhawatiran akan mendapatkan stigma buruk dari masyarakat.

Walaupun tato mulai mendapatkan ruang di dalam masyarakat kita, namun keberadaan tato tetap saja dianggap negatif dan dipandang sebelah mata.Masih adanya anggapan buruk tersebut bukan tidak beralasan. Anggapan tersebut terus bertahan karena banyak pelaku kriminal yang kebetulan bertato, seperti yang bisa disiarkan di media massa.Motivasi dan faktor penyebab seseorang bertato bermacam-macam.Mulai dari keperluan upacara keagamaan, untuk memperingati sesuatu sampai hanya ikut-ikutan tren dan fashion.Tato juga dapat disimbolkan sebagai bentuk seni, perlawanan dan ungkapan perasaan oleh pemiliknya.Dalam penelitian yang berhubungan dengan stigma, maka peneliti akan menggunakan teori stigma yang dikemukakan oleh Ervin Goffman. Stigma merupakan tanda-tanda yang dibuat pada tubuh seseorang untuk diperlihatkan dan menginformasikan kepada masyarakat bahwa orang-orang yang mempunyai tanda-tanda tersebut merupakan seorang buruh, criminal, atau seorang penghianat.Tanda-tanda 
tersebut merupakan suatu ungkapan atas ketidak wajaran dan keburukan status moral yang dimiliki oleh seseorang (Goffman, 1963:1).

2) Perilaku diskriminasif pada perempuan bertato

Diskrimintif adalah sikap yang merupakan usaha untuk membedakan secara sengaja terhadap golongan-golongan yang berkaitan dengan kepentingan tertentu ; dalam diskriminatif, golongan tertentu diperlakukan berbeda dengan golongan-golongan lain ; pembedaan itu dapat didasarkan pada suku bangsa, agama, mayoritas, atau bahkan minoritas dalam masyarakat, diskriminatif adalah bersifat aktif atau aspek yang dapat terlihat dari prasangka yang bersifat negative terhadap seorang individu atau suatu kelompok. "Diskriminatif mencakup perilaku apa saja, yang berdasarkan perbedaan yang dibuat berdasarkan alamiah atau pengkategorian masyarakat, yang tidak ada hubungannya dengan kemampuan individu.

3) Dampak satigmatisasi dan perilaku diskriminatif pada perempuan bertato

Beberapa penyebab masyarakat mengstigmatisasi bahkan mendiskriminasi perempuan yang menggunakan tato, berdasarkan kacamata masyarakat bahkan isu-isu yang beredar dilingkungan sangatlah benar adanya, bahwa rata-rata perempuan yang menggunakan tato tidak pernah lepas dari kriminal bahkan tak memiliki aturan, tetapi perluh jika diketahui bahwasanya tidak semua perempuan menggguna tato adalah perempuan yang brutal, ada kalanya perempuan menggunakan tato hanya sebatas minat dan bahkan pengaruh dari lingkungan saja akibat pergaulan yang terlalu bebas dan diluar jangkauan atau pengawasan keluarga, teori Stigmatisasi merupakan tanda-tanda yang dibuat pada tubuh seseorang untuk diperlihatkan dan menginformasikan kepada masyarakat bahwa orang-orang yang mempunyai tanda-tanda tersebut merupakan seorang buruh, criminal, atau seorang penghianat. Teori labeling ini adalah pemberian cap atau label terhadap seseorang yang sudah dicap oleh masyarakat kepada orang yang diberikan label karena adanya tindakan perilaku menyimpang. Oleh sebab itu perempuan pengguna tato dicap sebagai perempuan melanggar norma-norma dan aturan yang berlaku.Saat ini, perempuan yang mentato tubuh tidak jarang untuk ditemukan. Sebagian dari mereka bahkan menggunakan pakaian yang cenderung memperlihatkan tato mereka. Menurut Kassandra (Aldy, 2007 ), perempuan bertato cenderung mengarah tipikal wanita yang eksibisionis. Kebanggaan dan keinginan menampilkan tato yang ada di bagian tertentu tubuhnya, termasuk kategori eksibisionis. Seolah perempuan bertato ingin memperlihatkan sisi kelembutannya dengan mewujudkan sebuah tato yang indah.Namun selain penyebab yang disebutkan diatas, masih ada lagi penyebab yang 
mendominasi penyebab terjadinya masyarakat mengstigmatisasi dan mendiskriminasi perempuan penggunan tato yang berada di Kelurahan Karunrung.

Dampak pribadi yang dirasakan subjek dalam penelitian ini adalah rasa percaya diri yang meningkat di lingkungan tertentu, namun akan merasa minder di lingkungan yang lain. Rasa percaya diri muncul jika subjek berada di lingkungan yang bersahabat dengan orang-orang bertato. Namun ketika subjek berada di lingkungan yang menganggap tato sebagai sesuatu hal yang tabu dan negatif maka subjek akan merasa minder dan tidak percaya diri karena khawatir mendapatkan penilaian dan perlakuan yang buruk dari lingkungan tersebut seperti distigma dan didiskiriminasi di mana subjek berada.

4) Solusi stigmatisasi dan perilaku diskriminatif pada perempuan bertato

Perempuan yang menggunkan tato tidak seharusnya distigma jelek dan didiskriminasi oleh masyarakat, karena pada dasarnya perempuan menggunakan tato takkan lepas dari dalam dirinya sendiri (internal) jika pendorong dalam diri sangat kuat maka akan terjadilah sesuatu yang di inginkan oleh subjek, begitu juga halnya dengan perempuan yang ingin menggunakan tato, mereka akan menggunakan tato ketika sudah yakin akan dirinya dan bisa menerima reziko yang akan diterima. Seperti pernyataan menurut Hatib Abdul Kadir Olong (2006: 16) kalangan muda menganggap tato sebagai simbol kebebasan dan keberagaman, akan tetapi bagi kalangan tua tato dianggap sebagai simbol keliaran atau segala sesuatu yang berbau negatif. Dengan demikian tato akan sangat tergantung pada tiga konteks pemaknaan, yakni kejadian historis, lokasi teks dan formasi budaya pembacanya. Hal tersebut seperti dampak sosial yang dialami oleh subjek pada penelitian ini yang mendapatkan perlakuan yang berbeda-beda dari tiap lingkungan. Contohnya keluarga yang paling berkaitan dengan subjek dan menganggap tato sebagai hal yang negatif maka tentu saja akan menentang keputusan bertato. Namun dampak yang diterima dari teman sebaya yang didominasi kaum muda dengan pemikiran yang lebih dinamis maka tidak akan menjadikan tato sebagai suatu masalah.

\section{KESIMPULAN}

1. Stigmatisasi masyarakat tentang perempuan bertato benar adanya, karena seorang perempuan tidak pantas untuk menggunakan tato karena tubuhnya kelihatan kotor dan seperti yang kita ketahui pula bahwa perempuan bertato identik dengan istilah kenakalan, meskipun sebenarnya banyak yang menggunakan tato hanya sekedar menganggap bahwa tato adalah sebuah seni. 
2. Masalah tentang diskriminasi tentang masyarakat terhadap perempuan bertato tidak salah, karena sudah jelas bahwa didalam Agama Islam menggunakan tato baik lakilaki maupun perempuan sangat diharamkan dan seharusnya jika menggunakan tato wajib menghapusnya. Laki-laki baik perempuan yang menggunakan tato hukumnya haram.

3. Dampak umum yang terjadi pada perempuan bertato adalah mereka akan merasakan malu, minder, dan akan membatasi pergaulannya dengan masyarakat sekitarnya dan akan terjadi anti sosial dalam lingkungan dimana perempuan bertato tinggal, dan ketika kita berbicara masalah agama islma maka tidak akan lepas dari pandangan tokoh agama mengatakan bahwa setiap muslim kita ini bersaudara sebab itu harusnya dalam masyarakat tidak mengenal yang namanya stigma ataupun harus mendiskriminasi, sebagaimana seorang perempuan perasaannya halus dan apabila sedikit menstigma dan mendikiriminasi mereka akan sangat merasa malu dan tidak akan bisa bergaul dilingkungan ia tinggal.

4. Solusi yang tepat dalam permasalahan ini adalah sebagaimana masyarakat harusnya merima penuh dan lebih bijak, harusnya juga perempuan yang menggunakan tato lebih baiknya cepat untuk memperbaiki diri sebagaimana mestinya agar kiranya dapat diterima dengan baik oleh masyarakat, begitupun sebagai pengguna tato harusnya menyadari bahwa seorang perempuan harus menjaga kebersihan tubuhnya meskipun sangat senang dalam dunia seni. Tujuan dari hasil penelitian ini adalah untuk mengklarifikasi dengan seksama, tak lupa juga dimana masalah timbul maka harus ada solusi, bahwasanya tidak semua perempuan yang menggunakan tato adalah perempuan yang tak lepas dari tindakan-tindakan yang tidak benar, meskipun kemungkinan besar perempuan yang menggunakan tato adalah perempuan nakal.

\section{Daftar Pustaka}

Prof. Dr. Sugiyono, (2011). Metode Penelitian Pendidikan Pendekatan Kuantitatif dan Kualitatif $R \& D$, Bandung: Alfabeta

Ritzer, George. Edisi kedelapan (2015).Teori Sosiologi. Celeban timur UH III/548 Yogyakarta 55167: Pustaka Pelajar

Seakanto, Soerjono. (2012). Sosiologi Suatu Pengantar. Jakarta: Rajawali

Seakanto, Soerjono. (2007). Sosiologi Suatu Pengantar. Jakarta: PT Raja Grafindo Persada 
Sujarweni, W.V. (2014). Metodologi Penelitian. Yogyakarta: Pustakabarupres

Sztompka, P. (2015). Sosiologi Perubahan Sosial. Jakarta: Prenada Media

Sugiono, (2008,)Metodologi penelitian Kuantitatif, kualitatif, dan R\&D, Alfabeta, bandung

Dr. Ulber Silalahi, Ma. (2012). Metode Penelitian Sosial. Bandung: PT Refika Aditama

Idrus Muhammad. (2009)Metode Penelitian Ilmu Sosial. Yogyakarta: Penerbit Erlangga.

J. Dwi Narwoko \& Bagong Suyanto 2011, Sosiologi Teks Pengantar Dan Terapan. Jakarta. Kencana

Moleong. (2006)Metode Penelitian Kualitatif. Bandung : PT. Remaja Rosdakarya

Sutopo, HB,( 2002) Metode penelitian kualitatif, PT. Remaja Rosda karya, Bandung, 